\title{
SSynthesis
}

International Scientific Conference of IT and Business-Related Research

\section{GLOBALIZACIJA I NJEN NEGATIVNI UTICAJ NA ZEMLJE U RAZVOJU}

\section{GLOBALIZATION AND ITS ADVERSE EFFECTS ON DEVELOPING COUNTRIES}

\author{
Gordana Mićunović ${ }^{1}$, Nataša Novaković ${ }^{1}$, Goran Stefanović ${ }^{2}$ \\ ${ }^{1}$ Visoka poslovna škola strukovnih studija, Kralja Petra I br. 70, Blace, Srbija \\ ${ }^{2}$ MK Mountain Resort, Hotel Grand, Kopaonik, Srbija
}

\begin{abstract}
Apstrakt:
Večita polemika između globalista i protivnika globalizacije (antiglobalista) o krajnjim posledicama globalizacije dobija sve više na značaju. U današnje vreme, kada su rezultati realizacije delova globalnih strategijskih planova više nego očigledni, primetno je i koju cenu su platile, plaćaju, i plaćaće zemlje u razvoju. Neke od najvažnijih posledica globalizacije uključuju recesiju, visoku stopu nezaposlenosti, kao i gubitak resursa od značaja za same države. To pokreće sledeća pitanja: Da li su nerazvijene zemlje samo instrument ka ostvarivanju globalnih strateških ciljeva? Da li u tom slučaju istovremeno mogu raditi i na unapređivanju privrednih i neprivredih delatnosti u svojoj zemlji i imati zdravu ekonomiju i socijalno okruženje? Intervensanje od strane državnih organa je neizbežno, ali nažalost nije im ostavljeno dovoljno prostora za manevar. Samim tim, ne možemo, a da se ne pozabavimo pitanjem prekrajanja teritorija, jer je i ono deo globalnih strategijskih planova. U ovom radu pokušaćemo da dođemo do odgovora na sva ova pitanja. Zaključak koji možemo izvesti jeste da proces globalizacije nije moguće zaustaviti, ali mu se možemo prilagoditi.
\end{abstract}

\section{Ključne reči:}

globalni strategijski planovi, zemlje u razvoju, intervencionizam, prekrajanje teritorija, resursi od značaja.

\section{UVOD}

Ljudska individua nije u stanju da u dužem periodu samostalno preživi u prirodi. Za njen opstanak bitna je saradnja sa drugim ljudima. Čovek je društveno biće. Opstaje samo kao deo šire ljudske zajednice, kao član društva (Veličković, 2000).

Brzi naučno-tehnološki razvoj dao je značajan doprinos procesu globalizacije. Visoko razvijene zemlje su značajnim ulaganjem u nauku i tehnologiju obezbedile sebi vođstvo u procesu globalizacije diktirajući tempo i teritorije njenog napretka. Globalizacija je prosec koji su zamislile i koji uspešno sprovode ekonomski jake i razvijene zemlje radi ostvarivanja profita. Pored nacionalnog razvojnog plana, razvijene zemlje donose i globalni strategijski plan, čiji se efekti manje ili više reflekutuju u svim zemljama sveta. Ne možemo da ne primetimo da proces globalizacije podseća, a sve više i poprima oblik nekog novog vida kolonijalizma koji podrazumeva kolonijalizaciju celog sveta. Ova činjenica je od ogromnog značaja, ako se ima u vidu rastuća ekonomska i tehnološka međuzavisnost u ekonomskom svetu (Bajec \& Joksimović, 2004). Malim zemljama, poput naše, koje su prešle sa centralno-planske na privredu sa slobodnim tržištem, sa čestim smenjivanjem vlade, sa zastarelom tehnologijom, sa mnogim neuspelim privatizacijama, recesijom privrede, još uvek ne okončanim procesom tranzicije, nije nimalo lako da

\section{Abstract:}

The everlasting controversy between globalists and those opposing globalization (anti-globalists) about the ultimate outcomes of the globalization process is gaining more and more significance. Nowadays, when the results of implementation of some segments of global strategic plans are more visible, the adverse effects on developing countries could be and shall be observed in the future. Some of the most prominent consequences of the globalization process include economic recession, high unemployment rate, and loss of resources of significance for the country itself. This imposes the following questions: Are the developing countries an instrument for achieving global strategic objectives? Can they simultaneously work on improving the overall economic and non - economic business activities in their country and have a stable economy and healthy public sphere? Even though interventionism of state governments is inevitable, they are not left much space to maneuver. Thus, we cannot avoid mentioning the issue of redrawing of territory, as it is part of global strategic plans. This paper shall attempt to provide answers to all these questions. The conclusion could be drawn that we cannot stop the process of globalization, but we can adapt to it.

\section{Key words:}

global strategic plans, developing countries, interventionism, the redrawing of territory, resources of significance.

se izbore za svoje mesto u globalnom svetu i da ostanu konkurentne, a da pritom rade na unapređenju i očuvanju resursa od značaja. Intervencionizam vlada zemalja je izražen u većoj meri i u ovim uslovima ga je nemoguće zaobići.

\section{ZEMLJE U RAZVOJU KAO INSTRUMENT OSTVARIVANJA GLOBALNIH STRATEŠKIH CILJEVA}

Savremeno međunarodno ekonomsko okruženje odlikuje proces globalizacije nacionalnih i regionalnih tržišta (Rosić \& Đurić, 2008). Danas se sve zemlje nalaze usred žestoke bitke za što povoljniji položaj u procesu globalizacije koju diktira savremena naučno-tehnološka revolucija (Bajec \& Joksimović, 2004). Najveći doprinos globalizaciji dala je tehnologija. Nekoliko tehnoloških proboja imalo je izuzetan značaj. Kompjuterska tehnologija je omogućila ulazak u novu razvojnu fazu finansijskih tržišta počev od 1971. godine i stvaranja kompjuterizovane trgovačke mreže NASDAQ. Drugi bitan momenat u razvoju tehnologije je jednostavniji i jeftiniji pristup satelitskim komunikacijama. Treći tehnološki proboj je, naravno, razvoj interneta (Šoškić \& Živković, 2007). Globalizacija zahteva multidisciplinarni pristup, ne možemo ekonomiju odvojiti od politike, kulturnih i tradicionalnih vrednosti, etike, obrazovanja, zdravstva 
i dr. Kada se sve nabrojano uzme u obzir može se zaključiti da korist od globalizacije nemaju sve zemlje sveta, već veoma mali broj zemalja. Kada se govori o pozitivnim efektima najpre se pomisli na slobodnu trgovinu, a da bi se imalo s čim trgovati privreda zemlje mora da ostvaruje rast. Zemlje čija je privreda u recesiji, ili nerazvijene zemlje, ne mogu govoriti o pozitivnim efektima globalizacije. Negativni efekti globalizacije vidljivi su u povećanju nezaposlenosti, smanjenju životnog standarda i kvaliteta života. Srbija još uvek nije u procesu globalizacije, ali i te kako oseća negativne efekte koji su posledica ispunjenja dela globalnih strateških planova. U procesu pridruživanja Evropskoj uniji (u daljem tekstu EU) Srbiji su postavljeni zahtevi bez čijih ispunjenja ne bi mogla da se nađe na putu ka članstvu u EU. Samim tim, Srbija na neposredan način učestvuje u procesu globalizacije. Mnogi zahtevi podrazumevaju i promenu nacionalno i kulturno utemeljenih vrednosti, odnosno, usaglašavanje sa standardima, zakonima i vrednostima zemalja članica EU. Globalizacija je istorijski proces koji se postepeno odvija u svim delovima sveta. Svetsko tržište preko globalizacije stavlja neke narode i mesta u sasvim nove okolnosti, nove odnose i pred nove probleme (Hrustić, 2010). Ekonomska globalizacija posmatra se kao sila koja najviše ugrožava autoritet nacionalne države (Lakić, 2011). U svakom slučaju nacionalne države gube suverenitet. Globalna ekonomija i globalna politika daju smernice, koje kao prioritet imaju ispunjenje globalnih ciljeva tzv. zemalja blagostanja. Zapad svoje kapije otvara za slobodno kretanje ljudi i robe samo ukoliko mu to donosi dobar profit. Nijedan uspešan domaćin neće otvoriti kapije svog imanja za druge subjekte ukoliko od toga ne očekuje značajnu korist. Radikalnim promenama zahvaćene su sve sfere, odnosno svi podsistemi koje podrazumeva jedno uređeno društvo kao sistem. Prema Veličkoviću (2011) privreda je samo deo, podsistem društva, i to najznačajniji. Za privredu se može reći da predstavlja ukupnost (celinu) svih privrednih resursa, privrednih subjekata i institucija jedne zemlje čiji skup interakcija ima karakter privrednih aktivnosti čiji je cilj ostvarenje korisnog rezultata (nacionalnog proizvoda). Na globalizaciju se mora gledati iz svih uglova jer zadire u sve pore jednog društva. Danas, pri pomenu globalizacije, najpre se pomisli na globalizaciju ekonomskih tokova. Treba li prihvati sve što sa sobom donosi globalizacija? Jaz između industrijalizovanih zemalja na severu i zemalja u razvoju na jugu, kao i jaz između bogatih i siromašnih sve je izraženiji čak i u zemljama u koje se sliva bogatstvo. Kolonije se, i posle toliko vremena po dobijanju nezavisnosti, još uvek nisu oporavile.

\section{ZEMLJE U RAZVOJU I EFEKTI GLOBALIZACIJE}

Kada su zemlje u razvoju u pitanju, ne možemo se složiti sa tim da je pozitivnih efekata više nego negativnih. Lošija ili bolja međunarodna saradnja je oduvek postojala. Kakva će ona biti zavisilo je od razvijenosti zemlje, raspoloživosti u resursima i od odnosa vladajućeg establišmenta sa okruženjem. Ako se od zemalja u razvoju zahteva da se odreknu svega što predstavlja njihov identitet, ako za svaki iole značajan korak treba da budu nečim uslovljene, postavlja se pitanje kakva je korist od globalizacije. Nakon rata na prostorima bivše Jugoslavije, u svim bivšim republikama, vidljive su posledice osiromašenja i stagnacije. Negativne posledice globalizacije u Srbiji ogledaju se u osiromašenju i nezadovoljstvu u svakom pogledu. Prostorno Srbija je manja nego ikad. Kosovo i Metohija raspolaže ogromnim rudnim bogatstvom što je samo jedan od pokazatelja gubitaka koje Srbija trpi u zadnjih petnaest godina, zbog nemogućnosti pristupa rudnicima. Ne možemo da ne primetimo da je iniciranje kriza u slabo razvijenim i nerazvijenim zemljama sastavni deo globalnih strateških planova koji sa sobom nose niz negativnih efekata. Globalni strateški planovi za zemlje u razvoju se mnogo ne razlikuju, može se reći da su skoro isti i da se za svaku zemlju radi tek poneka korekcija. Profit jeste pokretač svega. Svaka velika svetska kriza prethodi ratovima, a svako novo „oslobođenje“ donosi i novo društveno uređenje, nove nacionalne strategije, politike i mere. To mnogo govori i naši savremenici ne mogu a da na pitanje Kosova i Metohije, odnosno Srbije, ne gledaju i iz ovog ugla. U svim zemljama u kojima je došlo do građanskog rata, uništena je godinama stvarana infrastruktura i zaustavljena proizvodnja, broj nezaposlenih je u stalnom porastu, a pad životnog standarda vidljiv je u svim delovima zemlje. Prelazak iz centralno-planskog modela privređivanja u tržišni kao i mnoge neuspele privatizacije ostavile su svoj pečat. Veliko je pitanje koliko je vremena potrebno da se proizvodnja pokrene, oporavi i ostvari kakav-takav rast. Integracija tržišta, država i tehnologija omogućila je pojedincima, korporacijama i državama da proizvodnju i svoju robu plasiraju brže i jeftinije čak i u najudaljenije krajeve sveta, ali to ne znači mnogo zemljama u razvoju koje su prethodno razorene na svim poljima. Države koje su sve vreme konkurentne ne biraju sredstva da zadrže konkurentnost. Transnacionalne korporacije u pravom smislu reči kontrolišu osnovne privredne, finansijske i tehnološke tokove u savremenim uslovima privređivanja. U ekonomski vodećim privredama u svetu, ogromna finansijska ulaganja u razvoj novih tehnologija dovela su do svojevrsne monopolizacije kapitala i tehnološke superiornosti pojedinih transnacionalnih korporacija. Vodeća transnacionalna preduzeća su uspevala da u kvalitetno izmenjenim uslovima privređivanja ostvare ogromne finansijske efekte čime su dodatno uvećala svoju dominaciju na globalnom planu (Cvetanović, 1999). Paradoks je da se nikada nije više govorilo o ljudskim pravima i humanosti.

Razvijene zemlje, koje su svojevremeno otpočele proces globalizacije, ne pogađaju gubici koje trpi privreda i društvo zemalja u razvoju. Shvativši značaj blizine sirovina, proizvodnje i tržišta, njihova proizvodnja je uglavnom dislocirana po raznim zemljama sa jeftinom radnom snagom i manjim troškovima. Taj komfor sebi mogu da priušte samo razvijene zemlje. Sa druge strane, građani zemalja u razvoju koje su odlučile da dislociraju svoju prozvodnju velikim delom ostaju bez posla što vremenom dovodi do sve većeg nezadovoljstva i socijalnih nemira. Proces globalizacije je nezaustavljiv. U zemljama širom sveta raste broj nezaposlenih. Pozitivne strane globalizacije koje su se najpre primetile i osetile više ne deluju privlačno, iako je probuđena svest o značaju međuzavisnosti. Za zemlje u razvoju pre bi se moglo reći da je to uslovljenost i zavisnost. Pored pozitivnih efekata, koje sa sobom nosi ovaj proces, vidljivi su i negativni efekti koji se odražavaju na zemlje u razvoju. Ipak, svim raspoloživim resursima i snagama treba se usmeriti i raditi na što bržem prilagođavanju zakonitostima svetskog tržišta. Gubitak resursa na Kosovu i Metohiji, neuspele privatizacije, stagnacija i recesija privrede, gubitak radnih mesta i sve veća nezaposlenost ne ostavljaju prostor za pogrešne poteze, a ono što se ni u kom slučaju ne sme dogoditi jeste izolacija.

\section{SRBIJA I STUBOVI KONKURENTNOSTI}

U teškom globalnom ekonomskom okruženju za Srbiju je veoma važno da realno sagleda sopstvenu ekonomsku situaciju i spozna svoju konkurentsku poziciju u odnosu na pozicije drugih svetskih zemalja (Lazić \& Markov, 2011). Strukturu globalnog indeksa konkurentnosti čini 12 pojedinačno opisanih stubova konkurentnosti koji nisu nezavisni već međusobno povezani sa tendencijom uticaja jednog stuba na jačanje drugog i obrnuto (Lazić \& Markov, 2011). Po stubovima konkurentnosti (konstitutivni elementi Globalnog indeksa konkurentnosti) koje 
ova dva autora navode u svom radu: institucije, infrastruktura, makroekonomska stabilnost, zdravlje i osnovno obrazovanje, visoko obrazovanje i usavršavanje, efikasnost robnog tržišta, efikasnost tržišta radne snage, efikasnost finansijskog tržišta, tehnološka spremnost, veličina tržišta, poslovna sofisticiranost i inovativnost. Stubovi konkurentnosti organizovani su u tri grupe. Prva grupa uključuje stubove institucije, infrastruktura, makroekonomska stabilnost, zdravstvo i primarno obrazovanje. Drugu grupu čine faktori povećanja efikasnosti koju formiraju stubovi visoko obrazovanje i obuka, efikasnost tržišta dobara, efikasnost tržišta rada, sofisticiranost finansijskog tržišta, tehnološka spremnost i veličina tržišta, dok su u trećoj grupi sofisticiranost poslovnih procesa i inovacija.

Po podacima Svetskog ekonomskog foruma za 2013-2014. godinu, Srbija se po vrednostima globalnog indeksa konkurentnosti (GIK) našla na nezavidnom 101. mestu što se može videti u sledećoj tabeli.

\begin{tabular}{|c|c|c|}
\hline \multicolumn{3}{|c|}{ Globalni indeks konkurentnosti 2013-2014. } \\
\hline Zemlja & Rang (od 148) & Skor (1-7) \\
\hline Crna Gora & 67 & 4,2 \\
\hline Albanija & 95 & 3,8 \\
\hline Bosna i Hercegovina & 87 & 4,0 \\
\hline Hrvatska & 75 & 4,1 \\
\hline Makedonija & 73 & 4,1 \\
\hline Srbija & 101 & 3,8 \\
\hline
\end{tabular}

Tabela 1. Vrednosti GIK za zemlje Zapadnog Balkana za period 2013-2014.

Izvor: Fondacija za razvoj ekonomske nauke

Prema ukupnoj konkurentnosti merenom GIK u 2013. godini, Srbija se nalazi na začelju grupe zemalja Zapadnog Balkana u koju spadaju Albanija, Bosna i Hercegovina, Hrvatska, Makedonija i Crna Gora. Istorijski posmatrano najveću vrednost GIK od 3,9 Srbija je ostvarila uoči prvog talasa globalne ekonomske krize 2008. godine, da bi već naredne, 2009. godine vrednost GIK primetno opala na 3,77 što se može videti iz tabele 2 koja daje prikaz kretanja GIK za zemlje Jugoistočne Evrope u periodu 2008-2010. godine Prema podacima Fondacije za razvoj ekonomske nauke (FREN), najkonkurentnija zemlja u svetu za 2014. godinu je Švajcarska koja ima najveću vrednost indeksa konkurentnosti (5,7), u Evropskoj uniji predvode Finska i Nemačka. Finska je sada četvrta u svetu, a Nemačka peta. SAD su na trećem mestu, odmah iza Singapura. Velika Britanija je na devetom mestu, Rusija na 53, Kina na 28, Turska na 45, Brazil na 57, a Indija na 71. Najnižu vrednost indeksa konkurentnosti od 2,79 i 144. mesto zabeležila je Gvineja. Izveštaj Fondacije za razvoj ekonomske nauke (FREN) pokazuje da je Srbija popravila poziciju na globalnoj listi konkurentnosti i zauzela 94 mesto među 144 države.

Bez posedovanja strategije koja podrazumeva dugoročan plan nijedno preduzeće ne može uspešno poslovati. Zbog čestog menjanja političkog miljea Srbija odavno nema nacionalnu strategiju, a za obezbeđivanje efikasne nacionalne strategije neophodno je sagledati realnu sliku o njenim mogućnostima u odnosu na raspoložive resurse i realnu sliku odnosa sa okruženjem. Kao što se vidi ključni faktor procesa globalizacije je rast konkurencije na globalnom planu, a konkurentnost imaju zemlje sa navedenim postavljenim stubovima koje Srbija nema. Institucionalno, fenomen globalizacije povezan je sa razvojem i afirmacijom vodećih transnacionalnih kompanija u svetu. Ova preduzeća predstavljaju osnovni izražajni oblik visoko internacionalizovane proizvodnje na svetskom planu i ključne nosioce savremenog tehničkog progresa u globalnim razmerama (Cvetanović, 1999). Politika i mere sprovode se kroz međunarodne finansijske institucije: Međunarodni monetarni fond (MMF), Svetska banka (SB) i Svetska trgovinska organizacija (STO).

\begin{tabular}{|c|c|c|c|}
\hline Zemlja & 2008. & 2009. & 2010. \\
\hline Estonija & 4,67 & 4,56 & 4,61 \\
\hline Letonija & 4,26 & 4,06 & 4,14 \\
\hline Litvanija & 4,45 & 4,3 & 4,38 \\
\hline Poljska & 4,28 & 4,33 & 4,51 \\
\hline Češka & 4,62 & 4,67 & 4,57 \\
\hline Slovačka & 4,4 & 4,31 & 4,25 \\
\hline Mađarska & 4,22 & 4,22 & 4,33 \\
\hline Rumunija & 4,1 & 4,11 & 4,16 \\
\hline Bugarska & 4,03 & 4,02 & 4,13 \\
\hline Slovenija & 4,5 & 4,55 & 4,42 \\
\hline Hrvatska & 4,22 & 4,03 & 4,04 \\
\hline Albanija & 3,55 & 3,72 & 3,94 \\
\hline $\begin{array}{c}\text { Bosna i Herce- } \\
\text { govina }\end{array}$ & 3,56 & 3,53 & 3,7 \\
\hline Makedonija & 3,87 & 3,95 & 4,02 \\
\hline Crna Gora & 4,11 & 4,16 & 4,36 \\
\hline Srbija & 3,9 & 3,77 & 3,84 \\
\hline
\end{tabular}

Tabela 2. Kretanje GIK za zemlje Jugoistočne Evrope u periodu 2008-2010.

Izvor: Autorski prikaz na osnovu podataka Fondacije za razvoj ekonomske nauke

Međunarodni monetarni fond osnovan je 1944. godine a zvanično počeo sa radom 1946. godine u Vašingtonu. MMF odobrava zemlji sa platnobilansnim problemima pristup svojim resursima pod određenim uslovima (Marčetić, 2012). MMF-ov program počinje kada je privreda neke zemlje u recesiji i kada Vlada zemlje zatraži finansijsku pomoć. Uslovi koje određuje MMF često ne mogu biti ispunjeni u predviđenim rokovima, a zna se da moraju biti ispunjeni pre isplate prve tranše. Mišljenja o sklapanju sporazuma sa MMF-om su podeljena. Diktirajući uslove sporazuma, MMF guši bilo kakvu raspravu s vladom zemlje zajmoprimca o alternativnim ekonomskim politikama, a naročito širu raspravu unutar same zemlje (Stiglitc, 2004). Međunarodna banka za obnovu i razvoj (IBRD) osnovana je 1945. godine, sa ciljem da obezbedi pomoć za razvoj nerazvijenim zemljama u svetu. Svetska banka (SB) se obično oslanja na to da MMF podstiče dužničke zemlje na sprovođenje ekonomske reforme (Rendi, 1997). Kao i MMF ni Svetsku banku i neke njene poteze nisu zaobišle mnoge kritike. Treća međunarodna finansijska institucija koja je deo ove trilaterale je Svetska trgovinska organizacija (STO). Članstvo u STO predstavlja jedan od ključnih koraka integracije zemlje u globalne ekonomske tokove, kao i neophodan korak u procesu pridruživanja Evropskoj uniji. Na regulisanje odnosa u obavljanju svetske trgovine najveći uticaj ima Svetska trgovinska organizacija (World Trade Organization-WTO). Ova organizacija je osnovana 1995. godine sa sedištem u Ženevi. Nastala je na temeljima i težnji Opšteg sporazuma o carinama i trgovini (General Agreement About Tariffs and Trade- GATT) (Đurić, 2003). Glavni cilj STO je da obezbedi da se trgovina odvija bez prepreka što je predviđeno multilateralnim sporazumima. GATT je osnovan 1947. godine (Privredna komora Beograda, 2004). Iz gore navedenog primećujemo da su tri ključne međunarodne organizacije nastale skoro istovremeno, s tim što je STO zasnovan na temeljima GATT-a. 


\section{ZAKLJUČAK}

Globalizacija je zahvaljujući naučno-tehnološkoj revoluciji i visokorazvijenim zemljama, nezaustavljiv proces kojim se obezbeđuje slobodan protok roba, usluga i ljudi između različitih država što podrazumeva i otvaranje nacionalnih granica. Sredstva za finansiranje naučno-tehnološkog razvoja poseduju visokorazvijene zemlje. Međutim, na proces globalizacije ne možemo gledati samo sa ekonomske strane. Ekonomska strana, odnosno, profit jeste glavni motiv nastanka globalizacije, koja zadire u sve pore jednog društvenog sistema. Da bi se aktivnosti, predviđene globalnim strategijskim planovima odvijale $\mathrm{u}$ pravcu postavljenog cilja neophodno je obezbediti uslove koji podrazumevaju promene u svim društvima i na svim poljima. Promene su, uglavnom, radikalne i bolne naročito u zemljama u razvoju. Prvi korak u sprovođenju promena jeste iniciranje kriza u malim zemljama i kreiranje pogodnog tla u pravcu koji podrazumevaju globalni strategijski planovi. Jedino tako mogu se stvoriti uslovi za realizaciju globalnih ciljeva čiji očekivani negativni efekti, koje u tom procesu trpe zemlje u razvoju, ne brinu mnogo kreatore planova. Privreda je glavni podsistem društva, stoga je neizbežno baviti se globalizacijom i iz političkog ugla. Uočljivo je da su krize i ratovi, izazvane u zemljama u razvoju, deo globalnih strateških planova, a njihove posledice neizbežno se odražavaju na ionako slabe stubove konkurentnosti. Zemlje, poput naše, koje su iz komunističkog prešle u demokratski sistem uređenja, sa državne na privatnu svojinu, sa velikim brojem neuspelih privatizacija (koje još uvek nisu završene), bombardovane zemlje sa uništenom infrastrukturom, izgubljenim resursima na prostoru Kosova i Metohije, sa privredom u recesiji i velikim brojem nezaposlenih čeka teška i mukotrpna borba za svoje mesto u globalnom svetu. Negativni efekti, iniciranih kriza od strane visokorazvijenih zemalja, vide se u svim sferama zemalja u razvoju. Vladama tih zemalja prostor za manevar je ograničen samom težnjom ka napretku. Napredak podrazumeva sklapanje sporazuma sa MMF-om, molbe Svetskoj banci i Svetskoj trgovinskoj organizaciji koja je u potpunoj saglasnosti sa politikom uslovljavanja MMF-a. Kako bi se ostvarili globalni ciljevi u službi visokorazvijenih zemalja su tri ključne međunarodne organizacije, koje su neretko podložne brojnim kritikama zbog definisanja politike i mera u odnosu na zemlje u razvoju. Onoliko koliko u tim uslovljavanjima budemo uspeli da se izborimo eliminacijom neprihvatljivog, toliko ćemo i krenuti putem oporavka-obnove infrastrukture i institucija, oživljavanja privrede i otvaranja novih radnih mesta, stvaranja stabilnog ekonomskog ambijenta, podizanja standarda i kvali- teta života. Mora se ići u pravcu neutralisanja i eliminacije svih osetnih negativnih efekata. Koliko budemo uspeli u tome, toliko ćemo biti konkurentni. U suprotnom, integracija tržišta, država i tehnologija koja je omogućila da se proizvodnja i roba plasiraju brže i jeftinije, ne znači mnogo zemljama u razvoju.

\section{LITERATURA}

Bajec, J., \& Joksimović, Lj. (2004). Savremeni provredni sistemi. Beograd: Ekonomski fakultet.

Cvetanović, S. (1999). Teorija i politika privrednog razvoja. Niš: Ekonomski fakultet.

Đurić, Z. (2003). Spoljnotrgovinsko i devizno poslovanje. Kosovo Polje - Blace: Viša poslovna škola.

Hrustić, H. (2010). Srbija i geoekonomska globalizacija, Zbornik Matice srpske za društvene nauke. 132, 25-40.

Lakić, N. (2011). Da li je globalizacija izazov ili pretnja nacionalnim državama kao dominantnom obliku političke organizacije. Bezbednost Zapadnog Balkana, 6(21), 6-17.

Lazić, B., \& Markov, J. (2011). Metodologija istraživanja konkurentnosti koju primenjuje svetski ekonomski forum. Poslovna ekonomija, 5 (1), 216.

Marčetić, M. (2012). Uloga MMF-a u održanju eksterne ravnoteže. Beograd: Autorsko izdanje.

Rosić, I., \& Đurić, D. (2008). Nacionalna ekonomija. Kosovska Mitrovica: Ekonomski fakultet Priština - Kosovska Mitrovica.

Rendi, Č. (1997). Vodič za početnike u svetskoj privredi. Beograd: Želind.

Stiglic, Dž. (2004). Protivrečnosti globalizacije. Beograd: Biblioteka Ekonomija trećeg puta.

Šoškić, D. \& Živković, B. (2007). Finansijska tržišta i institucije. Beograd: Ekonomski fakultet.

Veličković, D. (2000). Način funkcionisanja privrede. Leposavić: Institut za srpsku kulturu Priština.

Fondacija za razvoj ekonomske nauke - FREN. (2014). Globalna ekonomska kriza i konkurentska pozicija Srbije. Preuzeto 11. marta 2015. http://www.fren.org.rs/sites/default/files/ projects/attachments/Izve\%C5\%A1taj\%202014\%20Globalna\%20ekonomska\%20kriza\%20i\%20konkurentska\%20 pozicija\%20Srbije.pdf

Privredna komora Beograda. (2004). Srbija i Svetska trgovinska organizacija-Perspektive i izazovi članstva. 16.03.2015. http:// www.kombeg.org.rs/Komora/udruzenja/UdruzenjeTrgovine.aspx?veza $=1409$ 